\title{
Herbicidal potential of phenolic and cyanogenic glycoside compounds isolated from Mediterranean plants
}

\author{
Afef Ladhari', Valeria Romanucci², Anna De Marco³, Gaetano De Tommaso², Cinzia Di Marino², \\ Giovanni Di Fabio ${ }^{2}$ and Armando Zarrelli*
}

\author{
${ }^{1}$ Department of Biology, Faculty of Sciences of Bizerte, Jarzouna 7021, Tunisia \\ ${ }^{2}$ Department of Chemical Sciences, University of Naples, Via Cintia 4, 80126, Italy \\ e-mail: zarrelli@unina.it \\ ${ }^{3}$ Department of Biology, University of Naples, Via Cintia 4, 80126, Italy
}

Received: 4 May 2018/ Accepted: 21 June 2018

\begin{abstract}
This study was conducted to test five phenolic and cyanogenic glycoside compounds for growth regulating activity on the germination and seedling growth of Portulaca oleracea L., Amaranthus retroflexus L., and Lactuca sativa L. at different concentrations. Overall, the tested compounds revealed growth-regulating activity in species-specific and concentration dependent manner. The most powerful effects were much pronounced on seedling growth rather than on germination. In fact, the compounds 1 (amygdalin) and 2 (salicylic acid) were the most phytotoxic on root growth of P. oleracea, and they caused, respectively, an inhibition of 55\% and $85 \%$ at $10^{-6} \mathrm{M}$ and $10^{-4} \mathrm{M}$. On the other hand, the lettuce seedling growth was more sensitive than weeds growth to the compounds 4 (3,4,5-trihydroxybenzoic acid) and 5 (7-hydroxycoumarin), which exhibited a moderate inhibition at the highest concentration. This selectivity and specificity of these active allelopathic compounds could be very useful for the development of new application of natural substances to control the aggressive weeds. Thus, our findings suggest that the integration of these compounds may maintain irrigation system and reduce the massive use of agrochemicals in agro-ecosystems.
\end{abstract}

Keywords: Allelochemicals, Amaranthus retroflexus, Portulaca oleracea, Lactuca sativa, Phytotoxicity, Weeds.

\section{Introduction}

In the recent years, the incessant application of agrochemicals for weed management may cause resistant weeds to the applied chemicals, and could lead to a severe threat to the environment and a major cause of soil pollution. Worldwide, it is expected that weeds are responsible for a loss of crop production of about $34 \%$ (Jabran et al., 2015), even when the crops are intensively controlled. Amaranthus retroflexus L. and Portulaca oleracea L. are the most aggressive weeds affecting several crops production all over the world. A. retroflexus is broadly dissemi- nated in 70 tropical and subtropical countries (Costea et al., 2004), and could lead to crop yield reductions of nearly $45 \%$ (Bensch et al., 2003). In addition, P. oleracea L. is widely distributed around the globe (Kim et al., 2015) and it may cause serious losses of crop production, estimated in approximately 50\% (Zauzah et al., 2016). These serious issues have become a main challenge for many agricultural producers. Yet, it remains difficult to develop generalized models to control aggressive weeds distribution. Researchers are looking for alternative strategies to manage weeds in field crops (Jamil et al., 2009). Allelopathy could be one of these alternatives: it is a complex interaction among plants including stimulatory as well as inhibi- 
tory influence (Rice, 1984) through biochemicals released into the environment. The allelochemicals are released in the soil from different plant parts through volatilization, root exudation, leaching and decomposition of plant residues. Therefore, considerable efforts have been dedicated to study the significant effect of several allelochemicals isolated from different Mediterranean plants, and their ability to control weeds in a sustainable manner (DellaGreca et al., 2003; DellaGreca et al., 2007; Fiorentino et al., 2007; Zarrelli et al., 2014). The active allelopathic compounds belong to different categories of secondary compounds such as phenols, benzoic and cinnamic acid derivatives, flavonoids, tannins, coumarins, terpenoids, alkaloids and polyacetylenes (Duke et al., 2000). Until 1988, it was estimated there were about 400,000 secondary metabolites (Einhelling et al., 1988). However, only 3\% has been identified, and some of their herbicidal allelochemicals have been identified (Vyvyan, 2002). This spectrum of allelochemicals makes them promising tools possessing specific properties for discovering novel and specific target sites in acceptor plants (Soltys et al., 2013). Once these substances are identified and characterized, they may be exploited as natural herbicides or to differentiate new eco-friendly herbicides (Zarrelli et al., 2014; DellaGreca et al., 2002; Ladhari et al., 2013; Ladhari et al., 2014). However, the mode of action of some allelochemicals is poorly studied in comparison to synthetic herbicides. In fact, the allelopathic compounds influence germination and growth of neighboring plants by disturbance of the physiological processes (Soltys et al., 2013); they may also bind to proteins at different sites than those in which synthetic herbicides are bound. Most of allelochemicals are totally or partially water-soluble which makes them easier to apply without additional surfactants (Dayan et al., 2009). Despite this progressive research, the herbicidal activity of some allelochemicals and their specific effect towards aggressive weeds remain enigmatic and still not well characterized. Thus, the aim of the present study was to evaluate the effects at different concentration of phenolic and cyanogenic glycoside compounds for growth regulating activity on the germination and seedling growth of the following aggressive weeds: P. oleracea L. (purslane) and A. retroflexus L. (pigweed), and of L. sativa L. (lettuce) (Cutillo et al., 2004; DellaGreca et al., 2004).

\section{Materials and methods}

\subsection{Target species and tested compounds}

An experiment was conducted in the growth chamber under controlled conditions. The aggressive weeds purslane and pigweed were selected because of their harmful effects in many crops worldwide, while lettuce was considered as a sensitive species to allelochemicals. The tested compounds were: amygdalin (1), salicylic acid (2), $O$-carboxybenzoic acid (3), 3,4,5-trihydroxybenzoic acid (4), 7-hydroxycoumarin (5), and 4-hydroxycoumarin (6) (Figure 1). These natural compounds were previously isolated from different Mediterranean plants among different chromatographic techniques and identified by NMR (DellaGreca et al., 2003; D’Abrosca et al., 2005; Cutillo et al., 2006). The phenolic compound $p$-hydroxybenzoic acid $\left(\mathrm{C}_{7} \mathrm{H}_{6} \mathrm{O}_{3}\right)$ (pHBA) was selected as a positive control for the present study, because its phytotoxicity has been previously described.

\subsection{Phytotoxic bioassays}

The target species of purslane, pigweed and lettuce were surface sterilized with $0.525 \mathrm{~g} \mathrm{~L}^{-1}$ sodium hypochlorite for $15 \mathrm{~min}$, then rinsed four times with deionized water, imbibed for $2 \mathrm{~h}$ at $22^{\circ} \mathrm{C}$ and carefully blotted using a folded paper towel. The seeds were selected for uniformity and the undersized or damaged seeds were discarded. For the assays, Petri dishes of $5 \mathrm{~cm}$ diameter with one sheet of filter paper (Whatman No. 1) as support were used. Test solutions $\left(10^{-4} \mathrm{M}\right)$ were prepared using $10 \mathrm{mM}$ MES buffer (=2-(N-morpholino) ethanesulfonic acid, $\mathrm{pH}$ 6). All tested compounds were dissolved in a ratio of 5:1 DMSO and buffer $\left(\mu 1 \mathrm{~mL}^{-1}\right)$, and four different concentrations were prepared at $10^{-4}, 10^{-5}, 10^{-6}$, and $10^{-7} \mathrm{M}$. The dissolved ratio of buffer and DMSO was considered as the negative control, and $p$-hydroxybenzoic acid (pHBA) as a positive control. The experiments were conducted in aqueous solution at controlled $\mathrm{pH}$. After the addition of 25 seeds and $2.5 \mathrm{~mL}$ of test solution, the Petri dishes were sealed with Parafilm ${ }^{\circledR}$ to ensure closed system models. The Petri plates were then placed in a growth chamber with $400 \mu \mathrm{mol}$ photons $\mathrm{m}^{-2} \mathrm{~s}^{-1}$ photosynthetically active radiation (PAR) at $24 / 22^{\circ} \mathrm{C}$ for $14 / 10 \mathrm{~h}$ light and dark periods, respectively. Treatments were arranged in a completely randomized design with three replications. The percentage of germination, shoot and root length of target species were determined daily over 5 days for the seedlings of purslane and pigweed, and 10 days for lettuce. Cumulative germination was determined by counting the number of germinated seeds at $24 \mathrm{~h}$ and transformed into germination percentage. Data were transformed to percent of control for analysis. The index of germination GI was determined using the following formula (Chiapuso et al., 1997):

$$
\begin{gathered}
\mathrm{GI}=\left(\mathrm{N}_{1}\right) * 1+\left(\mathrm{N}_{2}-\mathrm{N}_{1}\right) * 1 / 2+\left(\mathrm{N}_{3}-\mathrm{N}_{2}\right) * 1 / 3+\ldots .+ \\
+\left(\mathrm{N}_{-}-\mathrm{N}_{\mathrm{n}-1}\right) * 1 / \mathrm{n}
\end{gathered}
$$

Where, $\mathrm{N}_{1}, \mathrm{~N}_{2}, \mathrm{~N}_{3}, \ldots ., \mathrm{N}_{\mathrm{n}}$ represent the proportion of germinated seeds observed afterwards $1,2,3, \ldots, n-1, n$ days. This index shows the delay in germination induced 
<smiles>N#CC(OC1OCCC2(O)C(CO)COC(C(O)C1O)C(O)C(O)C2O)c1ccccc1</smiles>

1<smiles>O=C(O)c1ccccc1O</smiles>

2<smiles>O=C(O)c1ccccc1C(=O)O</smiles>

3<smiles>O=C(O)c1cc(O)c(O)c(O)c1</smiles>

4<smiles>O=c1ccc2ccc(O)cc2o1</smiles>

5<smiles>O=c1cc(O)c2ccccc2o1</smiles>

6

Figure 1. Structure of tested compounds

by the extract (Delabays et al., 1998). The inhibitory or stimulatory percent was calculated using the following equation given by Chung et al. (2001):

Inhibition $(-) /$ stimulation $(+) \%=[($ compound - control $) /$ control] $\times 100$

where control is the parameter measured in presence of distilled water instead of the tested compound.

\section{Statistical analysis}

The experiment was conducted in a complete randomized design with three replications and a $t$-test was performed to evaluate the effects of compounds in comparison with control values. ANOVA and post hoc LSD tests were performed with PASW Statistics 18, for Windows program, to analyze treatment differences. The means were separated on the basis of least significant differences at the 0.05 probability level.

\section{Results and discussions}

The germination of target species was not significantly affected by the tested compounds at different concentrations (Figure 2). The range of germination values (\%) had a lower bound for all the tested concentrations, however, no trend was found between germination and increasing levels of compounds. It is remarkable that the pHBA possesses an inhibitor effect on the germination for all the tar- get species compared to the tested compounds. The maximum of inhibition (of 21\%) was induced by the compound 5 on the germination of the pigweed at the highest concentration (Figure 2a). This phytotoxic effect was recorded by the compounds $\mathbf{1}$ and $\mathbf{3}$ to which the target species revealed an average inhibition of $15 \%$ at the highest concentration. However, a slight stimulation of $2 \%$ was recorded by the compound 6 at $10^{-4} \mathrm{M}$. A similar stimulation effect was observed by the compounds $\mathbf{2}$ and $\mathbf{4}$ at different concentrations.

The germination of lettuce was slightly affected by the compounds $3,4,5$, and 6 , which induced an average inhibition of $8 \%$ (Figure $2 \mathrm{~b}$ ). On the contrary, the lettuce germination was stimulated by the compounds $\mathbf{1}$ and $\mathbf{2}$ no more than $7 \%$. The germination of purslane was slightly inhibited (4\%) by the compound 1 , which was then slightly stimulated $(6 \%)$ by the other tested compounds (Figure 2c). These results are in accordance with Ladhari et al. (2013) who confirmed that some phenolic compounds induce inhibition on the germination of lettuce and some weed species. The phenolic compounds have been regarded as natural inhibitors of germination (Rice, 1984). Generally, allelochemicals could inhibit specific metabolic pathways and may suppress germination through their effect on respiration. This sensitivity could be explained by the selective permeability of seed coats (Wierzbicka \& Obidzińska, 1998) that act as a barrier between the embryo and its environment.

The results of the phytotoxicity assays were briefly summarized in Table 1. Overall, our results showed that 
(A)

A. retroflexus

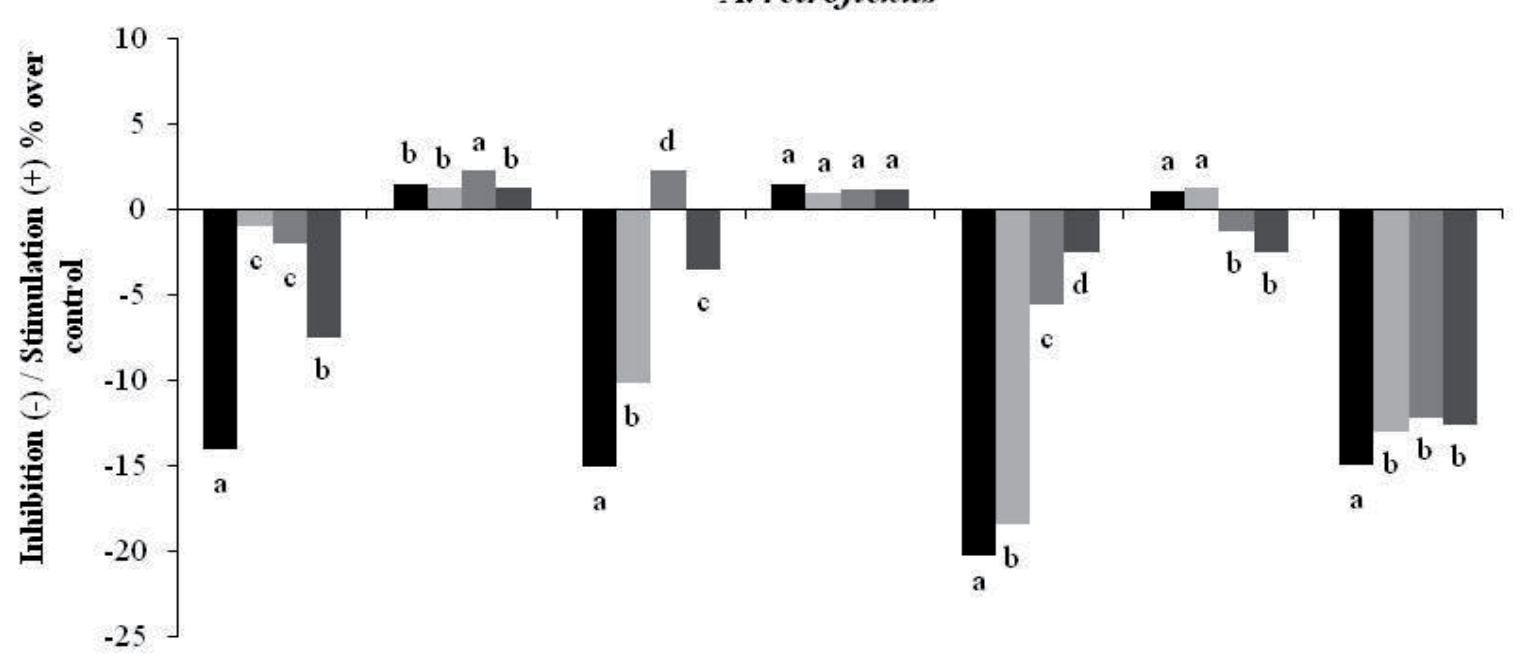

L. sativa

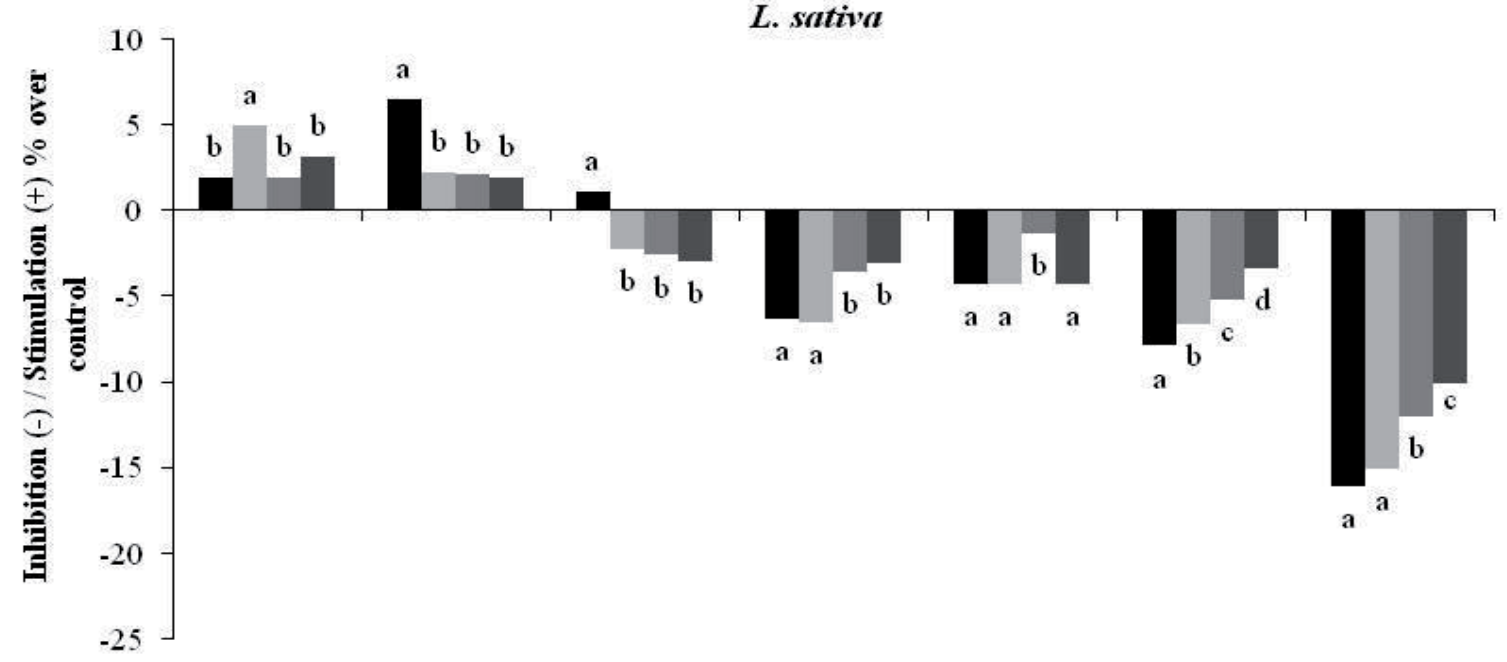

(B)

- 10-4 M

$10-5 \mathrm{M}$

-10-6 M

-10-7 M

(C)

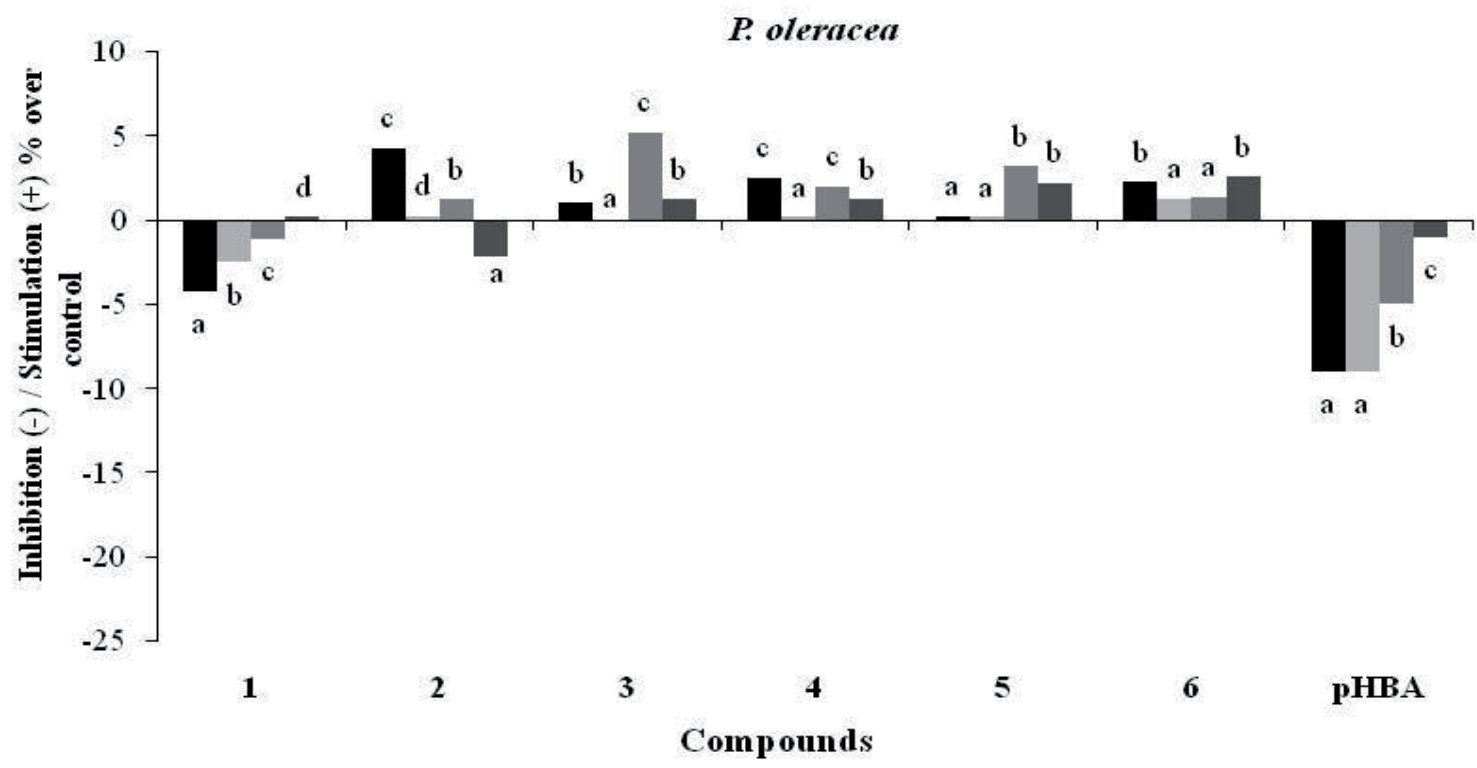

- 10-4 M

$10-5 \mathrm{M}$

10-7 M
- 10-4 M

$10-5 \mathrm{M}$

-10-6 M

-10-7 M

Figure 2. Effect of compounds 1-6 and pHBA on germination of A. retroflexus (A), L. sativa (B), and P. oleracea (C). Means with the same letter in a column are not significantly different at $\mathrm{P}<0.05$ (LSD test) 
Table 1: Comparison of the effects of compounds 1-6 on germination, shoot and root length of $A$. retroflexus, L. sativa, and $P$. oleracea. Range of inhibition: (-) $<15 \%$ ); (--) $<30 \%$; (---) $<60 \%$; Range of stimulation: $(+)<30)$; (++) $<60 \%$; (+++) $>60 \%$.

\begin{tabular}{|c|c|c|c|c|c|c|c|c|}
\hline & & \multicolumn{6}{|c|}{ Compounds } & \\
\hline & & 1 & 2 & 3 & 4 & 5 & 6 & \\
\hline \multirow{9}{*}{ 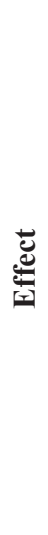 } & \multirow{3}{*}{ Germination } & - & & - & & -- & - & A. retroflexus \\
\hline & & & & - & - & - & - & L. sativa \\
\hline & & & & & & & & P. oleracea \\
\hline & \multirow{3}{*}{ Shoot length } & - & - & -- & & - & + & A. retroflexus \\
\hline & & ++ & ++ & & --- & --- & --- & L. sativa \\
\hline & & --- & -- & -- & & ++ & + & P. oleracea \\
\hline & \multirow{3}{*}{ Root length } & -- & & --- & + & --- & & A. retroflexus \\
\hline & & ++ & +++ & & --- & --- & -- & L. sativa \\
\hline & & --- & --- & ++ & ++ & +++ & ++ & P. oleracea \\
\hline
\end{tabular}

the seedling growth was more sensitive to the tested compounds than germination. The shoot length was significantly affected by the tested compounds depending on the target species and applied concentrations (Figure 3 ). The compounds $\mathbf{4}$ and $\mathbf{6}$ seem to enhance the shoot growth of pigweed with the maximum of stimulation of $15 \%$ and $30 \%$, respectively, at $10^{-4} \mathrm{M}$, and no more than $10 \%$ at $10^{-7}$ M (Figure 3a). The shoot growth of lettuce was the most sensitive to the tested compounds (Figure 3b). Generally, all the tested compounds revealed a significant phytotoxic effect on lettuce seedling growth and the highest inhibition (of 60\%) was induced by the compound 4 at the highest concentration. Whereas, the compounds $\mathbf{1}$ and $\mathbf{2}$ exhibited a significant stimulation of $40 \%$ and $120 \%$ at the $10^{-4} \mathrm{M}$, respectively (Figure 3b). On the other hand, the purslane shoot length was moderately inhibited by the compound 1 at the highest and lowest concentrations (Figure 3c). Similar effect was revealed also by the compound 5 at the $10^{-7}$ $\mathrm{M}$, but a moderate stimulation of $50 \%$ was observed at $10^{-5}$ M. In addition, the inhibitory effects was much pronounced on roots rather than on shoots, and roots were considered the main target tissue to the phytotoxic substances. The root growth of the target species was significantly affected by the tested compounds at different concentrations (Figure 4). The phytotoxic effect was markedly induced by the compounds 3, 5 and $\mathbf{6}$ with an average inhibition of $40 \%$ on the root length of pigweed at $10^{-4} \mathrm{M}$ (Figure $4 \mathrm{a}$ ). Similarly, lettuce root length was markedly inhibited (60\%) by compound $\mathbf{4}$ at the highest concentration, but insignificant inhibition (less than 10\%) was induced by the compound 6 (Figure 4b).

On the other side, significant stimulation of $110 \%$ was exhibited by the compound $\mathbf{2}$ on lettuce root length at the
$10^{-4} \mathrm{M}$. The compounds $\mathbf{1}$ and $\mathbf{2}$ were the most active on the root growth of purslane; they induced an inhibition of 60 and $75 \%$, respectively, at the highest concentration (Figure $4 \mathrm{c}$ ). In addition, these compounds induced a respective inhibition of $35 \%$ and $15 \%$ on root length of pigweed at the highest concentration. However, the compounds $\mathbf{3}$ and 5 revealed a considerable stimulation of $90 \%$ and $110 \%$, respectively, at $10^{-6}$ and $10^{-5} \mathrm{M}$ (Figure $4 \mathrm{c}$ ). This result was supported by the study of Meksawat and Pornprom (2010) who reported that root length has a high sensitivity to allelochemicals. The inhibitory effect of the accumulated compounds in root growth was explained by the hindered arrangement of the microtubule during cell division (Singh et al., 2002) or by expansion of the shoot and root cells (Zimdahl, 1999).

In our findings, the allelopathic potential is speciesspecific and depends on the concentrations of the applied compounds. We found that $A$. retroflexus was less sensitive to the tested compounds compared to the other target species of L. sativa and P. oleracea. The compounds 4 (3,4,5-trihydroxybenzoic acid), 5 (7-hydroxycoumarin) and 6 (4-hydroxycoumarin) induced a significant stimulation on the root growth of P. oleracea compared to the shoot growth. However, these compounds induced a significant inhibition on lettuce roots and shoots growth with slight inhibition on germination. The pattern of stimulation at different concentrations was in order $\mathbf{5}>\mathbf{4}>\mathbf{6}$ while the inhibition effect was much pronounced by $\mathbf{4}$ and $\mathbf{5}$ compared to the compound 6. Similar results were observed by Pan et al. (2015) who revealed that the 7-hydroxycoumarin (compound 5) had significant inhibition on seedling growth of purslane and lettuce, more than 4-hydroxycoumarin (compound 6). This phytotoxic effect could be explained by the 
(A)

再
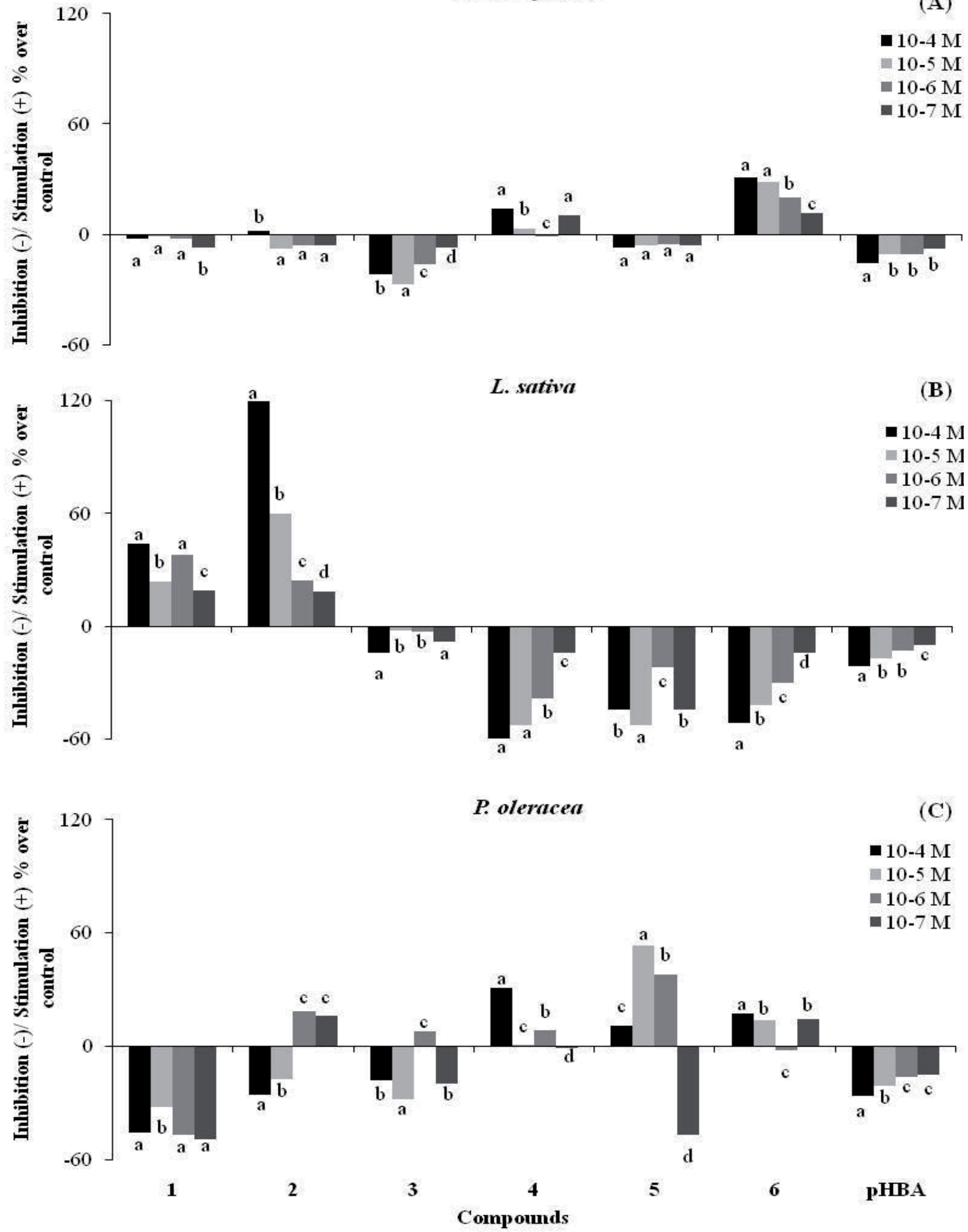

Figure 3. Effect of compounds 1-6 and pHBA on shoot length of A. retroflexus (A), L. sativa (B), and P. oleracea (C). Means with the same letter in a column are not significantly different at $\mathrm{P}<0.05$ (LSD test) 

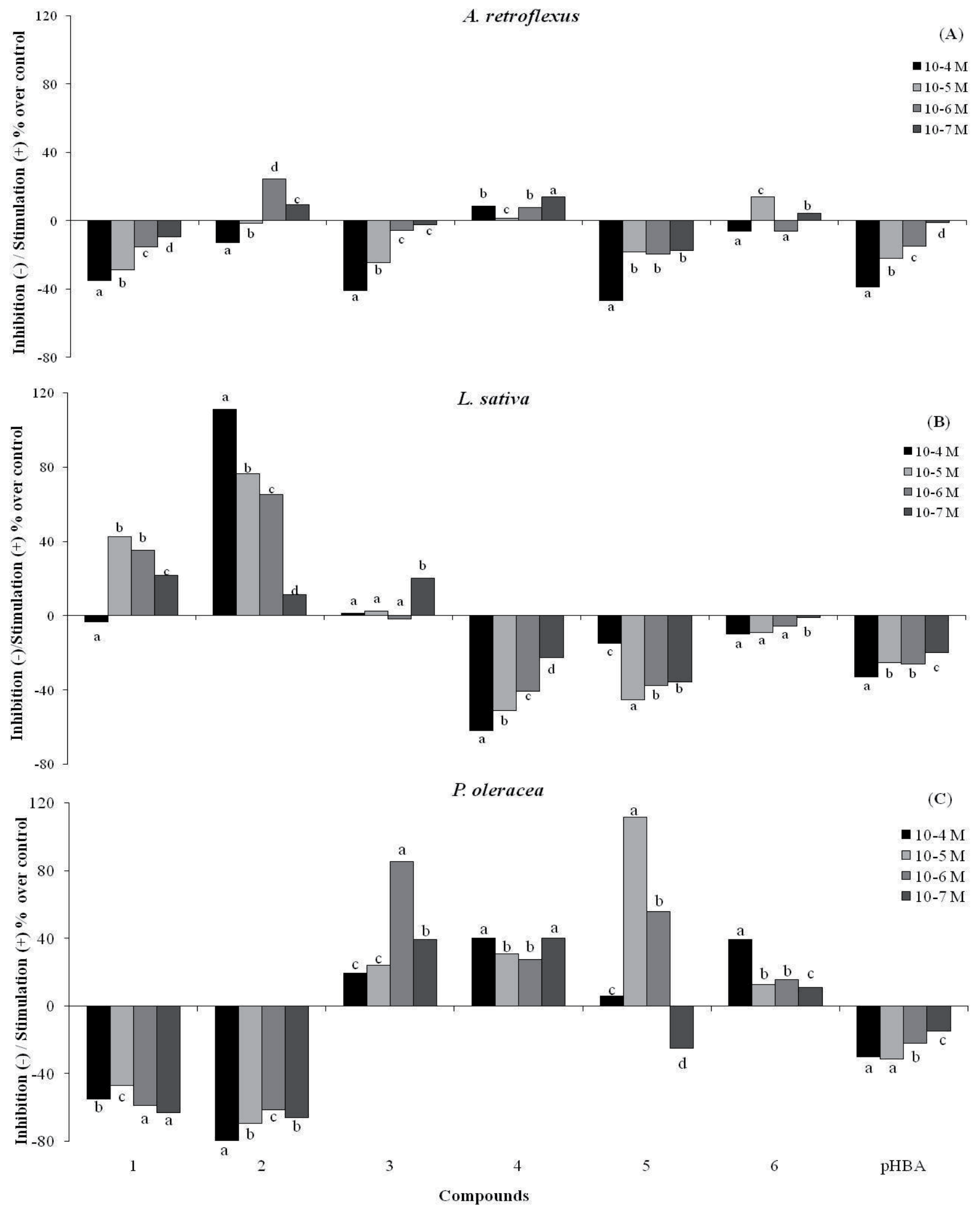

Figure 4. Effect of compounds 1-6 and pHBA on root length of A. retroflexus (A), L. sativa (B), and P. oleracea (C). Means with the same letter in a column are not significantly different at $\mathrm{P}<0.05$ (LSD test) 
varied structure of coumarins that depends on the numbers and positions of hydroxyl groups. In fact, the C7 hydroxyl groups in 7-hydroxycoumarin (compound 5) was important for increasing the activity of coumarin (Pan et al., 2015). According to Pergo et al. (2008), the coumarin is a species-specific and concentration-dependent, with a stimulatory and inhibitory effects at low and high concentrations, respectively (Abenavoli et al., 2006). Generally, coumarin is widely dispersed in plant and can influence several physiological and biochemical processes of germination (Pergo et al., 2008), respiration, root growth, nitrate uptake and metabolism (Abenavoli et al., 2003), and photosynthesis (Moreland \& Novitzky, 1987). Jansson and Svensson (1980) reported that coumarins could exert an auxin-like activity to regulate the growth of plants. Knypl (1970) found that coumarin exhibited phytotoxicity by inhibiting cellular respiration process, but 7-hydroxycoumarin did not reduce the rate of respiration. Despite the inhibitory effect of 7-hydroxycoumarin, the stimulatory effect has not been observed previously and its mode of action still remains enigmatic. Its stimulatory action could be explained by the important role on the development of plant, not only defense. Earlier investigations indicated that coumarin changed root cell polarity of growth, causing an inhibition of longitudinal root cell elongation accompanied by a simultaneous stimulation of radial expansion (Avers \& Goodwin, 1956; Svensson, 1971). This knowledge may be more useful for a better understanding of the mode of action of 7-hydroxycoumarin. On the other hand, the compounds $\mathbf{1}$ (amygdalin) and $\mathbf{2}$ (salicylic acid) induced a significant stimulation on root and shoot growth of lettuce, while the purslane was inhibited by these compounds. According to Khodary (2004) and BoroumandJazi et al. (2011), salicylic acid induced a stimulation effect on shoot and roots of maize under stress condition. However, effects of salicylic acid revealed an inhibitory effect on seed germination, seedling growth, of four cowpea ( Vigna unguiculata) genotypes (Chandra et al., 2007). Hence, this interference indicates that salicylic acid caused a water stress (Barkosky \& Einhellig, 1993).

\section{Conclusion}

In conclusion, the knowledge on selectivity and specificity of the tested compounds could be very useful for the development of new application of natural compounds to control aggressive weeds. The outcomes of this study can be useful to understand the mode of action of the tested natural compounds, permitting the development of new strategies reducing the massive use of agrochemicals in agro-ecosystems.

\section{Acknowledgments}

This study was supported by AIPRAS Onlus (Associazione Italiana per la Promozione delle Ricerche sull'Ambiente e la Salute umana).

\section{References}

Abenavoli M.R., Sorgonà A., Sidari M., Badiani M. \& Cacco G., 2003, Coumarin inhibits the growth of carrot (Daucus carota L. cv. Saint Valery) cells in suspension culture, Journal of Plant Physiology 160: 227-237.

Abenavoli M.R., Cacco G., Sorgonà A., Marabottini R., Paolacci A.R. \& Ciaffi M., 2006, The inhibitory effects of coumarin on the germination of durum wheat (Triticum turgidum ssp. durum, cv. Simeto) seeds, Journal of Chemical Ecology 32: 489-506.

Avers C.J. \& Goodwin R.H., 1956, Studies on root. IV. Effects of coumarin and scopoletin on the standard root growth pattern of Phleum pratense, American Journal of Botany 43: 612-620.

Barkosky R.R. \& Einhellig F.A., 1993, Effects of salicylic acid on plant-water relationships, Journal of Chemical Ecology 19: 237-247.

Bensch C.N., Horak M.J. \& Peterson D., 2003, Interference of redroot pigweed (Amaranthus retroflexus), Palmer amaranth (A. palmeri), and common waterhemp (A. rudis) in soybean, Weed Science 51: 37-43.

BoroumandJazi S., Lariyazdi H. \& Ranjbar M., 2011, Effect of salicylic acid on some plant growth parameters under lead stress in Brassica napus var. Okapi, Iranian Journal of Plant Physiology 1: 177- 185.

Chandra A., Anand A. \& Dubey A., 2007, Effect of salicylic acid on morphological and biochemical attributes in cowpea, Journal of Environmental Biology 28:193196.

Chiapuso G., Sanchez A.M., Reigosa M.J., Gonzalez L. \& Pellissier F., 1997, Do germination indices adequately reflect allelochemical effects on the germination process? Journal of Chemical Ecology 23: 2445-2453.

Chung I.M., Ahn J.K. \& Yun S.J., 2001, Assessment of allelopathic potential of barnyard grass (Echinochloa crus-galli) on rice (Oryza sativa L.) cultivars, Crop Protection 20: 921-928.

Costea M., Weaver S.E. \& Tardif F.J., 2004, The biology of Canadian weeds. 130. Amaranthus retroflexus L., A. powellii S. Watson and $A$. hybridus L. Canadian Journal of Plant Science, 84(2): 631-668.

Cutillo F., D’Abrosca B., DellaGreca M. \& Zarrelli A., 2004, Chenoalbicin a novel cinnamic acid amide alkaloid from Chenopodium album. Chemistry and Biodiversity 1: 1579-1583. 
Cutillo F., DellaGreca M., Gionti M., Previtera L. \& Zarrelli A., 2006, Phenols and lignans from Chenopodium album, Phytochemical Analysis 17: 344-349.

Dayan F.E., Howell J. \& Widenhamer J.D., 2009, Dynamic root exudation of sorgoleone and its in planta mechanism of action, Journal of Experimental Botany 60: 2107-2117.

Delabays N., Ançay A. \& Mermillod G., 1998, Recherche d'espèces végétales à propriétés allélopathiques, Revue suisse de viticulture arboriculture horticulture 30: 383387.

DellaGreca M., Fiorentino A., Monaco P., Previtera L. \& Zarrelli A., 2002, A new dimeric 9,10-dihydrophenanthrenoid from the rhizome of Juncus acutus, Tetrahedron Letter 43(14), 2573-2575.

DellaGreca M., Fiorentino A., Monaco P., Previtera L., Zarrelli A. 2003, New dimeric phenanthrenoids from the rhizomes of Juncus acutus, structure determination and antialgal activity, Tetrahedron 59(13): 2317-2324.

DellaGreca M., Isidori M., Lavorgna M., Monaco P., Previtera L. \& Zarrelli A., 2004, Bioactivity of phenanthrenes from Juncus acutus on Selenastrum capricornutum, Journal of Chemical Ecology 30: 867-879.

DellaGreca M., Fiorentino A., Izzo A., Napoli F., Purcaro R. \& Zarrelli A., 2007, Phytotoxicity of secondary metabolites from Aptenia cordifolia, Chemistry and Biodiversity 4(2): 118-128.

Duke S.O., Dayan F.E., Romagni J.G. \& Rimando A.M., 2000, Natural products as sources of herbicides: current status and future trends, Weed Research 40(1): 99-111.

D’Abrosca B., DellaGreca M., Fiorentino A., Monaco P., Natale A., Oriano P. \& Zarrelli A., 2005, Structural characterization of phytotoxic terpenoids from Cestrum parqui, Phytochemistry 66: 2681-2688.

Einhelling F.A. \& Leather G.R., 1988, Potentials for exploiting allelopathy to enhance crop production, Journal of Chemical Ecology, 14(10): 1829-1844.

Fiorentino A., DellaGreca M., D’Abrosca B., Oriano P., Golino A., Izzo A., Zarrelli A. \& Monaco P., 2007, Lignans neolignans and sesquilignans from Cestrum parqui l'Her, Biochemical Systematics and Ecology 35(6): 392-396.

Jabran K., Mahajan G., Sardana V. \& Chauhan B.S., 2015, Allelopathy for weed control in agricultural systems, Crop Protection 72: 57-65.

Jamil M., Cheema Z.A., Mushtaq M.N., Farooq M. \& Cheema M.A., 2009, Alternative control of wild oat and canary grass in wheat fields by allelopathic plant water extracts, Agronomy for Sustainable Development 29(3): 475-482.

Jansson E. \& Svensson S.B., 1980, Coumarin effects on glycine max hypocotyl explains. Physiologia Plantarum 48: 486-490.
Khodary S.E.A., 2004, Effect of salicylic acid on the growth, photosynthesis and carbohydrate metabolism in salt-stressed maize plants, International Journal of Agriculture and Biology 6: 5-8.

Kim J.Y., Oh H.M., Kwak S.C., Cheon Y.H., Lee M.S., Rho M.C. \& Oh J., 2015, Purslane suppresses osteoclast differentiation and bone resorbing activity via inhibition of Akt/GSK3 $\beta$-c-Fos-NFATc1 signaling in vitro and prevents lipopolysaccharide-induced bone loss in vivo, Biological and Pharmaceutical Bulletin 38(1): 66-74.

Knypl J.S., 1970, Arrest of yellowing and senescing leaf discs of maize by growth retardants, coumarin and inhibitors of RNA and protein synthesis, Biologia Plantarum 12: 199-207.

Ladhari A., Omezzine F., DellaGreca M., Zarrelli A., Zuppolini S. \& Haouala R., 2013, Phytotoxic activity of Cleome arabica $\mathrm{L}$. and its principal discovered active compounds, South African Journal of Botany 88: 341351.

Ladhari A., Omezzine F. \& Haouala R., 2014, The impact of Tunisian Capparidaceae species on cytological physiological and biochemical mechanisms in lettuce, South African Journal of Botany 93: 222-230.

Meksawat S. \& Pornprom T., 2010, Allelopathic effect of itch grass (Rottboellia cochinchinensis) on seed germination and plant growth, Weed Biology and Management 10: 16-24.

Moreland E.D. \& Novitzky W.P., 1987, Effects of acid coumarins and flavonoids on isolated chloroplast and mitochondria. In: Waller GR, editor. Allelochemicals: Role in agriculture and forestry, American Society Symposium Series. Washington, American Chemical Society.

Pan L., Li X., Yan Z., Guo H. \& Qin B., 2015, Phytotoxicity of umbelliferone and its analogs: Structure-activity relationships and action mechanisms, Plant Physiology and Biochemistry 97: 272-277.

Pergo E.R., Abrahim D., da Silva P.C.S., Kern K.A., da Silva L.J., Voll E., Ishii-Iwamoto E.L. 2008, Bidens pilosa L. exhibits high sensitivity to coumarin in comparison with three other weed species, Journal of Chemical Ecology 34: 499-450.

Rice E.L. 1984, Allelopathy, Academic Press, New York, NY, USA.

Singh H.P., Batish D.R. \& Kohli R.K., 2002, Allelopathic effect of two volatile monoterpenes against bill goat weed (Ageratum conyzoides L.), Crop Protection 21: 347-350.

Soltys D., Krasuska U., Bogatek R. \& Gniazdowska A., 2013, Allelochemicals as bioherbicides - present and perspectives, Edited by A.J. Price and J.A. Kelton.

Svensson S.B., 1971, The effect of coumarin on root growth and root histology, Physiolgia Plantarum 24: 446-447. 